\author{
Iryna Kachkurkina, Valery Ovcharov and Olena Shevchenko
}

\title{
THE USAGE OF OIL REFINING INDUSTRY WASTE AS VULCANIZATION ACTIVE INGREDIENT OF ELASTOMERIC COMPOSITION S
}

\author{
State Higher Educational Institution «Ukrainian State Chemical Technological University» \\ 8 Gagarin's Ave., 49005 Dnipropetrovsk, Ukraine \\ svoks@inbox.ru
}

Received: October 13, 2008

(C) Kachkurkina I., Ovcharov V., Schevchenko O., 2009

\begin{abstract}
The influence of composite component perlite $\mathrm{DPh}-\mathrm{Zn}$, that is the waste of oil refining industry, on the formation of properties complex of rubber mixes and their vulcanizates on the basis of apolar cis-1,4-polyisoprene and butadiene-nitrile rubbers of various polarity has been investigated. It has been established that perlite $\mathrm{DPh}-\mathrm{Zn}$ is the effective vulcanization active component of multifunctional action capable at 10.0 mass frac. concentration to replace in full or in part traditional accelerators, vulcanization activators, stabilizers, and can be recommended for use in industrial elastomeric compositions for rubber goods manufacturing.
\end{abstract}

Keywords: oil refining waste, motor oils additive, perlite $\mathrm{DPh}-\mathrm{Zn}$, elastomeric composition, multifunctional action component, cis-1,4-polyisoprene rubber, butadiene-nitrile rubber, accelerator, activator, stabilizer.

\section{Introduction}

The modern problem of limitation and irretrievability of oil base stocks, which are the main suppliers of raw materials for the organic synthesis enterprises, causes the necessity of maximum effective use of the chemical industry secondary materials, as well as the environmental contamination prevention. One of consumers of various chemical enterprises wastes can be rubber industry because there is a deficiency of traditional components assortment in this branch and only the fourth part of them is issued in Ukraine [1]. The source of raw materials for elastomeric production can be oil refining wastes, for example, the wastes at manufacture of additives for motor oils on the basis of metals dialkyldithiophosphates. Hundreds tons of perlite used for purification of dialkyldithiophosphates from initial reagents excess at a final stage of synthesis, do not find applications and are the wastes polluting environment and demanding recycling.
Perlite DPh-Zn is the waste after purification of zinc dialkyldithiophosphate, which is the basic component for the production of industrial antioxiditive, anticorrosive and antiwear additives for motor oils. Natural aluminosilicate - perlite is used for purification from zinc oxide excess as a filtering material.

Synthesis of the additive, representing $50 \%$ solution of zinc isobutylisooctyldithiophosphate in oil, in the general view includes following stages [3]:

- interaction of isobutyl and isooctyl alcohols with quinquevalent phosphorus sulphide:

$$
4 \mathrm{ROH}+\mathrm{P}_{2} \mathrm{~S}_{5} \longrightarrow 2(\mathrm{RO})_{2} \mathrm{P}>_{\mathrm{SH}}^{\mathrm{SH}}+\mathrm{H}_{2} \mathrm{~S}
$$

where $\mathrm{R}=-\mathrm{CH}_{2}-\mathrm{CH}\left(\mathrm{CH}_{3}\right)_{2} ;-\mathrm{CH}_{2}-\mathrm{CH}-\left(\mathrm{CH}_{2}\right)_{3}-\mathrm{CH}_{3}$ (ratio $3: 1)$;

- neutralization of isobutylisooctyldithiophosphoric acid ethers by zinc oxide excess:
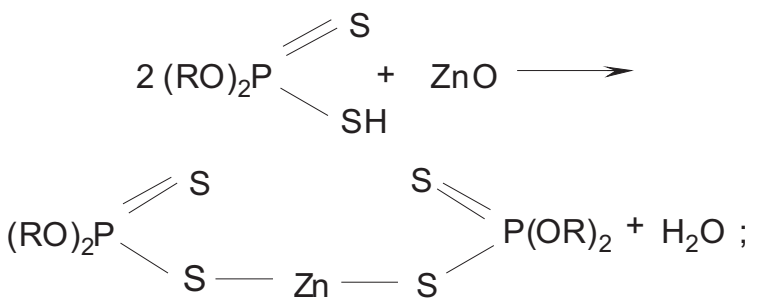

- purification of received zinc isobutylisooctyldithiophosphate from initial reagents excess;

- dissolution of zinc isobutylisooctyldithiophosphate in oil with obtaining of $50 \%$ solution.

Perlite $\mathrm{DPh}-\mathrm{Zn}$ is non-dusty and nontoxical powder of grey colour with the following composition (\%): perlite - 56.8; zinc oxide - 28.8; zinc isobutylisooctyldithiophosphate - 14.4.

Perlite $\mathrm{DPh}-\mathrm{Zn}$ action as a vulcanization active component of rubber mixes on the basis of cis-1,4- 
polyisoprene rubber and butadiene-nitrile rubbers of different polarities has been studied for the estimation of possibility of elimination or reduction of the sulfuric vulcanization systems traditional components (accelerators, activators, stabilizers) at earlier established optimum concentration 10.0 mass frac. for 100.0 mass frac. of rubber [4].

At present phosphorusorganic compounds, including dialkyldithiophosphates of metals, are used in elastomeric manufacture as the components of multifunctional purposes showing activating, accelerating and stabilizing action, therefore the investigations on studying the influence of this class components on formation of rubber mixes and their vulcanizates properties are very urgent and have not been finished yet [2].

The composite component perlite DPh-Zn as elastomeric materials ingredient became the research object of the given work.

\section{Experimental}

Investigations were carried out as follows:

- research of accelerating and activating action of perlite $\mathrm{DPh}-\mathrm{Zn}$ (10.0 mass frac.) in modeling rubber mixes on the basis of cis-1,4-polyisoprene rubber at a partial elimination of sulfuric vulcanization group of the traditional accelerator (diphenylguanidine) and at full elimination of activators (zinc oxide, stearic acid).

$$
\mathrm{M}, \mathrm{dN}^{*} \mathrm{~m}
$$

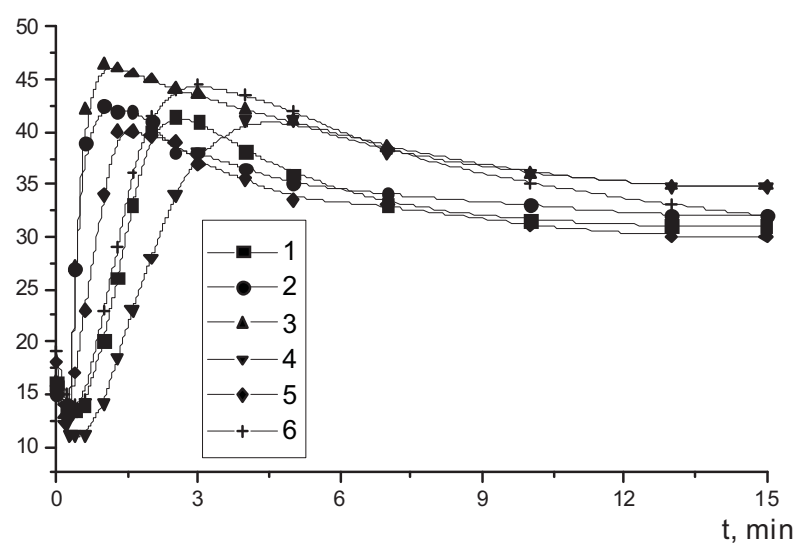

Fig. 1. The influence of vulcanization group structure (mass frac.) on vulcanization kinetic of modeling elastomeric compositions on the basis of cis-1,4-polyisoprene at $433 \mathrm{~K}$ : 1 (control) - diphenylguanidine + zinc oxide + stearic acid $(3.0+5.0+1.0)$;

2 - diphenylguanidine + stearic acid + perlite $\mathrm{DPh}-\mathrm{Zn}$ $(3.0+1.0+10.0)$;

3 - diphenylguanidine + zinc oxide + perlite DPh-Zn $(3.0+5.0+10.0)$; $4-$ diphenylguanidine + zinc oxide + stearic acid + perlite DPh-Zn $(1.0+5.0+1.0+10.0)$;

5 - diphenylguanidine + perlite $\mathrm{DPh}-\mathrm{Zn}(3.0+10.0)$;

6 - diphenylguanidine + perlite DPh-Zn $(1.0+10.0)$.
- research of accelerating and activating action of perlite $\mathrm{DPh}-\mathrm{Zn}$ (10.0 mass frac.) in modeling rubber mixes on the basis of polar butadiene-nitrile rubber BNR-18 at a partial or full elimination of sulfuric vulcanization group of the traditional accelerator (2-mercaptobenzothiazole) and activators (zinc oxide, stearic acid).

- research of accelerating, activating and stabilizing action of perlite $\mathrm{DPh}-\mathrm{Zn}$ (5.0 and 10.0 mass frac.) in industrial compositions for rubber goods manufacturing on the basis of more polar butadiene-nitrile rubber BNR26 at full elimination of known ingredients di-(2benzothiazolyl)-disulfide accelerator and amine type stabilizer - product $4010 \mathrm{NA}$, partial or full replacement of zinc oxide and at reduction of tetramethylthiuramdisulfide and stearic acid dosages.

Manufacturing and tests of elastomeric compositions were carried out according to existing techniques and requirements of state standards [5-7].

\section{Results and Discussion}

Kinetic curves of sulfuric vulcanization process of modeling elastomeric compositions on the basis of cis1,4-polyisoprene rubber at temperatures $416 \mathrm{~K}$ and $433 \mathrm{~K}$ are represented in Fig. 1. The results of calculation of mixes basic vulcanization parameters by rheometer data are shown in Table 1. Apparently, all tested rubber mixes on the basis of cis-1,4-polyisoprene are characterized by narrow vulcanization plateau and reversion relatively to the torque moment independently of vulcanization group structure that is caused by specific tendency of elastomeric compositions on the basis of polyisoprene rubbers to loss their properties during long-continued vulcanization [8].

The analysis of kinetic parameters at $416 \mathrm{~K}$ (Table 1) testifies that perlite $\mathrm{DPh}-\mathrm{Zn}$ introduction (10.0 mass frac.) increases the crosslinking degree, reduces the breakdown time (except for mixes 4 and 6) and increases the optimum curing time in comparison with corresponding parameters of control rubber mix without the composite additive and independently of traditional accelerators and activators contents. Vulcanization process of elastomeric compositions is the same at $433 \mathrm{~K}$. So, at $416 \mathrm{~K}$ the presence of perlite DPh-Zn (10.0 mass frac.) in the mixtures increases crosslinking degree by $25 \%$ and curing rate in 1.5 times; at higher temperatures the acceleration of crosslinking process is remained, nevertheless, the value of crosslinking degree increases only by $15 \%$. An optimum complex of kinetic properties at preservation of the breakdown time, high curing rate and crosslinking degree has the composition without known activators, but with the accelerator (reduced by $2 / 3$ ) and 10.0 mass frac. of perlite $\mathrm{DPh}-\mathrm{Zn}$.

Results of tests of vulcanizates physico-mechanical properties under standard conditions (Table 1) show the correlation dependence between crosslinking degree and 
Table 1

Structure and properties of modeling elastomeric compositions on the basis of cis-1,4 polyisoprene

\begin{tabular}{|c|c|c|c|c|c|c|}
\hline \multirow{2}{*}{ Component / Parameter } & \multicolumn{6}{|c|}{ Number of composition } \\
\hline & 1 & 2 & 3 & 4 & 5 & 6 \\
\hline \multicolumn{7}{|c|}{ Structure, mass frac.: } \\
\hline Diphenylguanidine & 3.0 & 3.0 & 3.0 & 1.0 & 3.0 & 1.0 \\
\hline Zinc oxide & 5.0 & - & 5.0 & 5.0 & - & - \\
\hline Stearic acid & 1.0 & 1.0 & - & 1.0 & - & - \\
\hline Perlite DPh-Zn & - & 10.0 & 10.0 & 10.0 & 10.0 & 10.0 \\
\hline \multicolumn{7}{|c|}{ Rheometer results at temperature $416 \mathrm{~K} / 433 \mathrm{~K}$ : } \\
\hline \multirow{2}{*}{ Minimum torque moment, $\mathrm{dN} \cdot \mathrm{m}$} & 16.0 & 15.0 & 17.0 & 14.0 & 16.0 & 16.0 \\
\hline & 13.5 & 13.0 & 13.0 & 11.0 & 14.0 & 14.0 \\
\hline \multirow{2}{*}{ Maximum torque moment, $\mathrm{dN} \cdot \mathrm{m}$} & 52.0 & 59.0 & 70.0 & 65.0 & 49.0 & 61.0 \\
\hline & 41.0 & 42.5 & 45.5 & 41.0 & 40.0 & 44.0 \\
\hline \multirow{2}{*}{ Crosslinking degree, $\mathrm{dN} \cdot \mathrm{m}$} & 36.0 & 44.0 & 53.0 & 51.0 & 33.0 & 45.0 \\
\hline & 27.5 & 29.5 & 32.5 & 30.5 & 26.0 & 30.0 \\
\hline \multirow{2}{*}{ Brealdown time, min } & 1.75 & 0.50 & 1.00 & 2.00 & 0.75 & 1.50 \\
\hline & 0.75 & 0.37 & 0.37 & 1.00 & 0.37 & 0.75 \\
\hline \multirow{2}{*}{ Optimum curing time, min } & 4.50 & 3.40 & 3.00 & 4.25 & 4.00 & 4.15 \\
\hline & 1.75 & 0.75 & 0.75 & 3.2 & 1.3 & 2.5 \\
\hline \multirow{2}{*}{ Curing rate, $\min ^{-1}$} & 13.09 & 16.15 & 18.23 & 20.01 & 21.17 & 20.91 \\
\hline & 27.50 & 33.92 & 38.28 & 42.02 & 44.46 & 43.91 \\
\hline \multicolumn{7}{|c|}{ Physical-mechanical properties of vulcanizates: } \\
\hline $300 \%$ Modulus, MPa & 5.2 & 5.9 & 8.0 & 7.6 & 5.1 & 6.9 \\
\hline \multicolumn{7}{|l|}{ Tensile strength, MPa: } \\
\hline $373 \mathrm{~K} \cdot 24 \mathrm{~h}$ & 18.1 & 15.8 & 15.4 & 15.3 & 18.0 & 17.5 \\
\hline $373 \mathrm{~K} \cdot 72 \mathrm{~h}$ & 15.0 & 12.9 & 13.1 & 12.9 & 14.8 & 14.7 \\
\hline \multicolumn{7}{|l|}{ Elongation, \%: } \\
\hline $373 \mathrm{~K} \cdot 24 \mathrm{~h}$ & 540 & 405 & 280 & 370 & 520 & 490 \\
\hline $373 \mathrm{~K} \cdot 72 \mathrm{~h}$ & 510 & 375 & 300 & 340 & 465 & 460 \\
\hline Residual elongation, $\%$ & 28 & 20 & 12 & 12 & 16 & 12 \\
\hline Shore A hardness & 65 & 63 & 69 & 65 & 63 & 65 \\
\hline Rebound elasticity, \% & 36 & 37 & 36 & 44 & 32 & 42 \\
\hline Tear resistance, $\mathrm{kN} / \mathrm{m}$ & 62 & 64 & 50 & 56 & 76 & 74 \\
\hline
\end{tabular}

engineering stress at $300 \%$ elongation. So, compositions containing perlite $\mathrm{DPh}-\mathrm{Zn}$ (10.0 mass frac.) have the high crosslinking degree and are characterized by the increased engineering stress at $300 \%$ elongation which, in turn, causes some reduction of tensile strength in comparison with control composition without a new component. The consequence of crosslinking degree increase is also the reduction of residual and relative elongation and increase of vulcanizates hardness. Comparison of the effect of traditional vulcanization system structure on the general complex of rubbers properties allows to assert that in the presence of perlite $\mathrm{DPh}-\mathrm{Zn}$ (10.0 mass frac.) the reduction of the accelerator contents and an elimination of known activators from the recipe (composition 6) does not worsen but relatively improves the level of elastic-strength characteristics concerning parameters of a control composition (without tested additive). So, the engineering stress at $300 \%$ elongation increases by $30 \%$, the tear resistance - by $20 \%$, the rebound elasticity - by $15 \%$ and the rubbers residual elongation decreases by $40 \%$.

The results of vulcanizates tests after thermal aging of the samples at $373 \mathrm{~K} \times 24 \mathrm{~h}$ and $373 \mathrm{~K} \times 72 \mathrm{~h}$ (Table 1) testify that in some cases the change of traditional vulcanization system structure negatively affects the preservation of rubbers elastic-strength properties after long thermal action which is reflected in increase of loss percent of parameter determined under tests standard conditions. Nevertheless, compositions with the perlite 
$\mathrm{DPh}-\mathrm{Zn}$ contents of 10.0 mass frac. at the elimination of activators and the accelerator concentration of 3.0 mass frac. (mix 5) or 1.0 mass frac. (mix 6) are the same as control rubber according to the values of tensile strength and elongation.

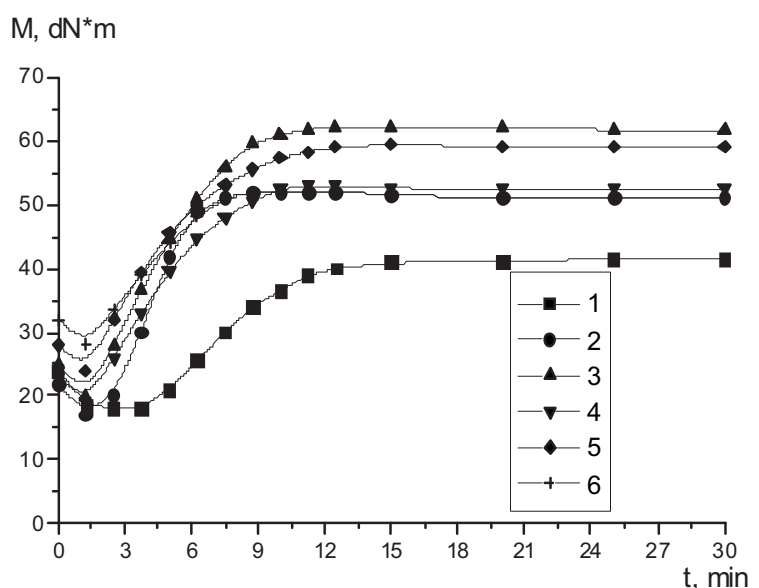

Fig. 2. The influence of vulcanization group structure (mass frac.) on vulcanization kinetic of modeling elastomeric compositions on the basis of butadiene-nitrile rubber BNR18 at temperature $433 \mathrm{~K}$ :

1 (control) - 2-mercaptobenzthiazole + zinc oxide + stearic acid $(1.5+5.0+1.5)$;

2 - 2-mercaptobenzothiazole + stearic acid + perlite $\mathrm{DPh}-\mathrm{Zn}$ $(1.5+1.5+10.0)$

3 - 2-mercaptobenzothiazole + zinc oxide + perlite $\mathrm{DPh}-\mathrm{Zn}$ $(1.5+5.0+10.0)$;

4 - 2-mercaptobenzothiazole + zinc oxide + stearic acid + perlite DPh-Zn $(0.8+5.0+1.5+10.0)$;

5 - 2-mercaptobenzothiazole + perlite DPh-Zn $(1.5+10.0)$;

$6-2$-mercaptobenzothiazole + perlite $\mathrm{DPh}-\mathrm{Zn}(0.8+10.0)$

The results of the experimental researches testify that the composite ingredient perlite $\mathrm{DPh}-\mathrm{Zn}$ in modeling rubber mixes and vulcanizates on the basis of $c i s-1,4-$ polyisoprene is the vulcanization active component of the multifunctional action, allowing to exclude from the recipe structure vulcanization activators - zinc oxide (5.0 mass frac.), stearic acid (1.0 mass frac.) and to reduce the diphenylguanidine accelerator contents by $2 / 3$, preserving at the same time satisfactory complex of elastomeric compositions of technological, vulcanization and physicomechanical properties.

The estimation of perlite DPh-Zn influence on a properties complex of elastomeric compositions on the butadiene-nitrile rubbers basis of various polarities became the following step of experimental researches.

Proceeding from rheometer data of elastomeric compositions at 416 and $433 \mathrm{~K}$ (Fig. 2, Table 2), the 10.0 mass frac. of perlite $\mathrm{DPh}-\mathrm{Zn}$ is more effective than 5.0 mass frac. of zinc oxide (mix 2), 1.5 mass frac. of stearic acid (mix 3) or 0.8 mass frac. of 2-mercaptobenzothiazole (mix 4). In a rubber mix on the basis of polar butadiene- nitrile rubber BNR-18 perlite $\mathrm{DPh}-\mathrm{Zn}$ is capable to carry out functions of zinc oxide and stearic acid (mix 5) simultaneously or zinc oxide, stearic acid and a part of 2-mercaptobenzothiazole (mix 6). It proves to be true also by data of vulcanizates physico-mechanical tests (Table 2). However, because of the increased crosslinking degree and perlite presence in a new component, rubbers with it are characterized by lower values of elongation, tensile strength and the increased hardness.

Generalizing the results of the carried out tests of rubber mixes and their vulcanizates it is possible to ascertain that an optimum complex of properties has the composition in which the full elimination of traditional activators (zinc oxide, stearic acid) is carried out and the dosage of the known accelerator (2-mercaptobenzothiazole) is half reduced at introduction of 10.0 mass frac. perlite DPh-Zn (mix 6). So, the given composition is characterized by the average increase in $35 \%$ of crosslinking degree, in $30 \%$ of curing rate at preservation of tensile strength, hardness, elasticity, tear resistance values and at twice reduction of residual elongation in comparison with control composition parameters (mix 1).

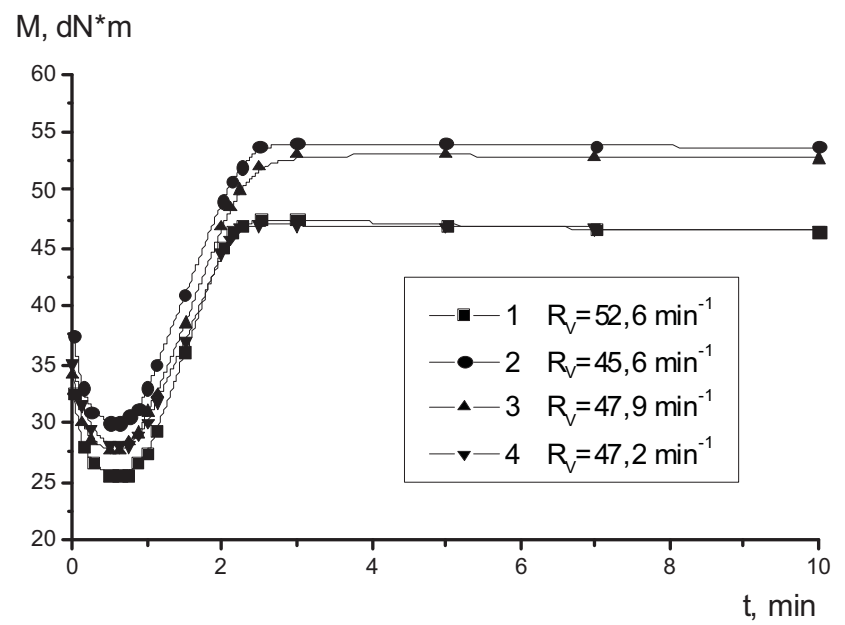

Fig. 3. The influence of vulcanization group structure (mass frac.) on vulcanization kinetic of elastomeric compositions on the basis of butadiene-nitrile rubber BNR26 for rubber goods manufacturing at $443 \mathrm{~K}$ :

1 (control) - tetramethylthiuramdisulfide + di- $(2-$

benzothiazolyl)-disulfide + zinc oxide + product $4010 \mathrm{NA}+$ stearic acid $(0.8+0.8+3.0+1.0+3.0)$;

2 - tetramethylthiuramdisulfide + zinc oxide + stearic acid + perlite $\mathrm{DPh}-\mathrm{Zn}(0.8+1.5+1.5+5.0)$;

3 - tetramethylthiuramdisulfide + zinc oxide + stearic acid + perlite DPh-Zn $(0.8+1.5+1.5+10.0)$;

4 - tetramethylthiuramdisulfide + stearic acid + perlite DPh$\mathrm{Zn}(0.6+1.5+10.0)$ 
Structure and properties of modeling elastomeric compositions on the basis of butadiene-nitrile rubber BNR-18

\begin{tabular}{|c|c|c|c|c|c|c|}
\hline \multirow{2}{*}{ Component / Parameter } & \multicolumn{6}{|c|}{ Number of composition } \\
\hline & 1 & 2 & 3 & 4 & 5 & 6 \\
\hline \multicolumn{7}{|c|}{ Structure, mass frac.: } \\
\hline 2-mercaptobenzothiazole & 1.5 & 1.5 & 1.5 & 0.8 & 1.5 & 0.8 \\
\hline Zinc oxide & 5.0 & - & 5.0 & 5.0 & - & - \\
\hline Stearic acid & 1.5 & 1.5 & - & 1.5 & - & - \\
\hline Perlite DPh-Zn & - & 10.0 & 10.0 & 10.0 & 10.0 & 10.0 \\
\hline \multicolumn{7}{|c|}{ Rheometer results at temperature $416 \mathrm{~K} / 433 \mathrm{~K}$ : } \\
\hline \multirow{2}{*}{ Minimum torque moment, $\mathrm{dN} \cdot \mathrm{m}$} & 22 & 22 & 22 & 22 & 20 & 25 \\
\hline & 18 & 17 & 20 & 19 & 24 & 28 \\
\hline \multirow{2}{*}{ Maximum torque moment, $\mathrm{dN} \cdot \mathrm{m}$} & $\underline{38}$ & $\underline{54}$ & $\underline{63}$ & 54 & $\underline{61}$ & $\underline{54}$ \\
\hline & 41 & 51 & 62 & 52 & 59 & 52 \\
\hline \multirow{2}{*}{ Crosslinking degree, $\mathrm{dN} \cdot \mathrm{m}$} & 16 & 32 & $\underline{41}$ & 32 & 41 & 29 \\
\hline & 23 & 34 & 42 & 33 & 35 & 24 \\
\hline \multirow{2}{*}{ Breakdown time, min } & 13.5 & $\underline{3.8}$ & 3.1 & 5.8 & 3.3 & 4.0 \\
\hline & 5.3 & 2.4 & 1.8 & 1.5 & 1.8 & 1.8 \\
\hline \multirow{2}{*}{ Optimum curing time, min } & 25.2 & 11.3 & 10.0 & 15.3 & 12.5 & 13.0 \\
\hline & 12.3 & 5.5 & 10.0 & 10.5 & 12.5 & 7.3 \\
\hline \multirow{2}{*}{ Curing rate, $\min ^{-1}$} & $\underline{8.5}$ & 13.3 & $\underline{14.5}$ & 10.5 & $\underline{10.9}$ & 11.1 \\
\hline & 14.3 & $\overline{32.3}$ & 12.2 & 11.1 & 9.3 & 18.2 \\
\hline \multicolumn{7}{|c|}{ Physico-mechanical properties of vulcanizates under tests standard conditions: } \\
\hline Tensile strength, MPa & 18.2 & 12.3 & 12.3 & 12.2 & 15.6 & 16.1 \\
\hline Elongation, \% & 565 & 220 & 195 & 225 & 240 & 280 \\
\hline Permanent elongation, $\%$ & 8 & 4 & 4 & 0 & 0 & 4 \\
\hline Shore A hardness & 71 & 74 & 76 & 75 & 74 & 72 \\
\hline Rebound elasticity, \% & 38 & 39 & 40 & 40 & 40 & 38 \\
\hline Tear resistance, $\mathrm{kN} / \mathrm{m}$ & 30 & 30 & 27 & 33 & 32 & 30 \\
\hline
\end{tabular}

Kinetic curves of vulcanization process of rubber mixes on the BNR-26 basis at temperature $443 \mathrm{~K}$ using the effective sulfuric vulcanization system of various structures are presented in Fig. 3. Apparently, the elastomeric compositions containing perlite $\mathrm{DPh}-\mathrm{Zn}$ by rheometer results insignificantly differ from the control mix. So, they possess close values to those of control parameters relatively to crosslinking degree and breakdown time. At the same time, the peculiaruty of tested mixes is the increase of optimum curing time. However, taking into consideration the calculated values of curing rate, the divergence from the control value does not exceed $10 \%$.

The analysis of vulcanizates physico-mechanical properties under standard conditions of tests (Fig. 4) shows a little change of compositions with perlite DPh$\mathrm{Zn}$ parameters in comparison with the control sample but they are in agreement with specifications and technical documentation requirements $\left(f_{p} \geq 10.0 \mathrm{MPa} ; \varepsilon \geq 120 \%\right.$; Shore A hardness $=75-85)$.

It is possible to predetermine the high stabilizing action of a composite component perlite DPh-Zn, 

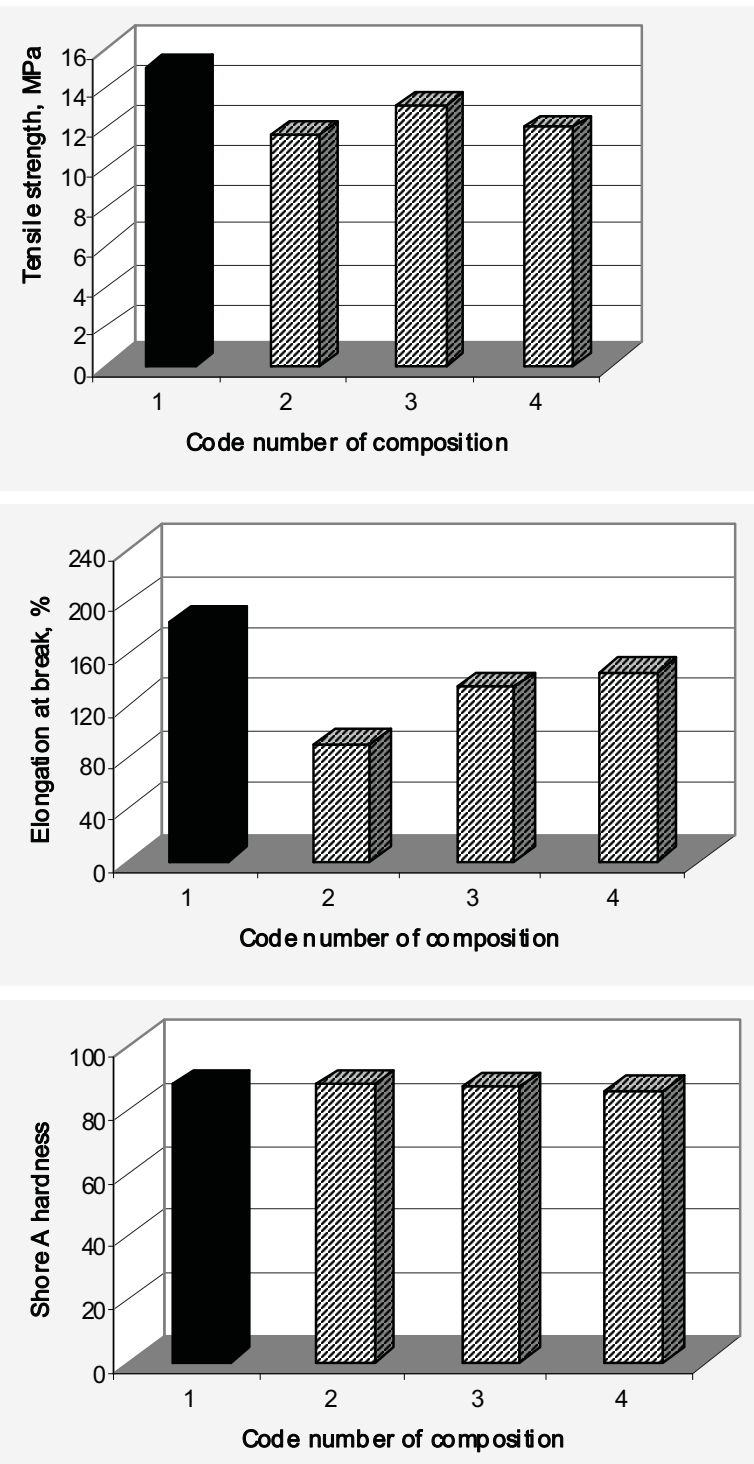

Fig. 4. The influence of vulcanization group structure (mass frac.) on physical-mechanical properties of elastomeric compositions on the basis of butadiene-nitrile rubber BNR-26 for rubber goods manufacturing: 1 (control) - tetramethylthiuramdisulfide + di- $(2-$ benzothiazolyl)-disulfide + zinc oxide + product $4010 \mathrm{NA}+$ stearic acid $(0.8+0.8+3.0+1.0+3.0)$;

2 - tetramethylthiuramdisulfide + zinc oxide + stearic acid + perlite $\mathrm{DPh}-\mathrm{Zn}(0.8+1.5+1.5+5.0)$;

3 - tetramethylthiuramdisulfide + zinc oxide + stearic acid + perlite DPh-Zn $(0.8+1.5+1.5+10.0)$;

4 - tetramethylthiuramdisulfide + stearic acid + perlite $\mathrm{DPh}$ $\mathrm{Zn}(0.6+1.5+10.0)$

1,4-polyisoprene and butadiene-nitrile rubbers of various polarities at preservation of their satisfactory complex of technological, vulcanization and physico-mechanical properties. Such traditional deficient components of rubber mixes as vulcanization accelerators of various classes (diphenylguanidine, 2-mercaptobenzothiazole, di-(2benzothiazolyl)-disulfide, tetramethylthiuramdisulfide), vulcanization activators (zinc oxide, stearic acid), stabilizers (4010 NA product) may be replaced in full or in part by perlite $\mathrm{DPh}-\mathrm{Zn}$ and it can be recommended for being used in industrial elastomeric compositions for rubber goods manufacturing.

\section{References}

[1] Maslosh V., Mikulenko L. and Strubchevskaya E.: Kauchuk i Rezina, 1996, 6, 34 .

[2] Ovcharov V., Shapkin A., Proycheva A. et al.: Tematichesky obzor. TsNIITEneftekhim, Moskwa 1984.

[3] Kuliev A.: Khimiya i tekhnologiya prisadok k maslam i toplivam. Khimiya, Leningrad 1985.

[4] Kachkurkina I., Ovcharov V. and Okhtina O.: V PolishUkrainian Conference, 2008, 46.

[5] Averko-Antonovich I. and Bikmullin R.: Metody issledovaniya struktury i svoystv polimerov. Nauka, Kazan 2002.

[6] Ovcharov V., Burmistr M., Smirnov A. et al: Svoystva rezinovyh smesey i rezin: otsenka, regulirovanie, stabilizatsiya., "SANT-TM", Moskwa 2001.

[7] Bergshteyn L.: Laboratorniy praktikum po tekhnologii reziny. Khimiya, Leningrad 1976.

[8] Devirts E.: Tematichesky obzor. TsNIITEneftekhim, Moskwa 1973.

\section{ВИКОРИСТАННЯ ВІДПАДУ НАФТОПЕРЕРОБНОӤ ПРОМИСЛОВОСТІ ЯК ВУЛКАНІЗАЦЙНО-АКТИВНОГО ІНГРЕДІЄНТУ ЕЛАСТОМЕРНИХ КОМПОЗИЦІЙ}

Анотація. Досліджено вплив композиційного інгредієнту - перліт ДФ-Zn, що являє собою відпад нафтопереробної промисловості, на формування комплексу властивостей гумових сумішей та їх вулканізатів на основі неполярного иис-1,4-поліізопренового та бутадісннітрильних каучуків різної полярності. Встановлено, що він є ефективним вулканізачійно-активним інгредіснтом поліфункціональноїдії, здатним при концентрачї 10,0 мас.час. цілком або частково замінити традиційні прискорювачі, активатори вулканізації, стабілізатори, іможе бути рекомендований для використання в промислових еластомерних композиціях для виготовлення формових гумо-технічних виробів.

Ключові слова: відпад нафтопереробки, присадка до моторних олив, перліт ДФ-Zn, еластомерна композиція, інгредієнт поліфункціональної дї, иис-1,4-поліізопрен, бутадієннітрильний каучук, прискорювач, активатор, стабілізатор. 